ELIOT IN PERSPECTIVE 


\section{ELIOT IN \\ PERSPECTIVE}

A SYMPOSIUM

edited by

GRAHAM MARTIN

MACMILLAN EDUCATION 
(C) Macmillan and Co 1970

Softcover reprint of the hardcover 1st edition 1970

First published in 1970 by

MACMILLAN AND CO LTD

Little Essex Street London w C 2

and also at Bombay Calcutta and Madras

Macmillan South Africa (Publishers) Pty Ltd Fohannesburg

The Macmillan Company of Australia Pty Ltd Melbourne

The Macmillan Company of Canada Ltd Toronto

Gill and Macmillan Ltd Dublin

ISBN 978-1-349-00605-2 ISBN 978-1-349-00603-8 (eBook)

DOI 10.1007/978-1-349-00603-8 


\section{Contents}

$\begin{array}{lr}\text { Acknowledgements } & 8\end{array}$

List of Abbreviations 9

Introduction II

I

F. W. BAteson The Poetry of Learning 3I

FRANCIS SCARFE Eliot and Nineteenth-century

French Poetry 45

DONALD DAVIE Pound and Eliot: a distinction $\quad 62$

GABRIEL PEARSON Eliot: an American use of symbolism 83

IAN HAMILTON The Waste Land 102

GRAHAM MARTIN Language and Belief in Eliot's

Poetry $I 12$

HAROLD F. BROOKS Four Quartets: the structure in relation to the themes 132

KATHARINE WORTH Eliot and the Living Theatre 148

2

RICHARD WOLlHeim Eliot and F. H. Bradley: an account

JOHN CHALKER Authority and Personality in Eliot's Criticism

ADRIAN CUNNINGHAM Continuity and Coherence in

Eliot's Religious Thought

MARTIN JARRETT-KERR 'Of Clerical Cut': retrospective reflections on Eliot's churchmanship 232

JOHN PETER Eliot and the Criterion 252

IAN GREGOR Eliot and Matthew Arnold 267

TERRY EAGLETON Eliot and a Common Culture 279

Notes on Contributors $\quad 296$

Index $\quad 298$ 


\section{Acknowledgements}

Acknowledgements are due to Faber \& Faber Ltd for the use of quotations from the works of T. S. Eliot, copyright in which belongs to Mrs Valerie Eliot. 


\section{List of Abbreviations}

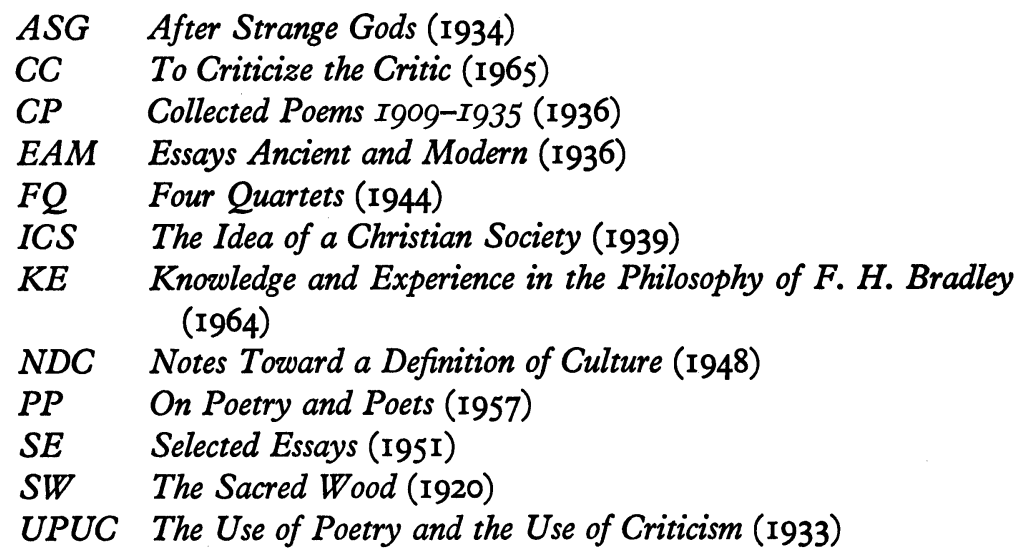

